\title{
EFEKTIVITAS KESIAPAN GURU, INFRASTRUKTUR DAN MOTIVASI BELAJAR SISWA TERHADAP KEBERHASILAN PENERAPAN KURIKULUM 2013 DI SMP KRISTEN KANAAN TANGERANG
}

\author{
Rinto Rain Barry \\ rintorainbarry@gmail.com \\ Business School, Pelita Harapan University
}

\begin{abstract}
The study looked at how to apply Teacher Readiness, Infrastructure, and Student Learning Motivation to the application of the 2013 Curriculum (Kurtilas) and the continued application of the 2013 Curriculum at the Canaan Christian Middle School in Tangerang as a case study. The research method used is quantitative research. Population of 8th and 9th grade students of Canaan Christian Middle School Tangerang. Payment sample of 60 students. Data collection is done by following a questionnaire conducted directly by the respondent. Furthermore, it was analyzed using the IBM SPSS Statistics 20. Program. The results showed that there were benefits from Teacher Readiness, Infrastructure, and Student Motivation in Canaan Christian Middle School in Tangerang, both partially and jointly on the Successful Implementation of the 2013 Curriculum. 2013 can be achieved by the readiness of teachers in terms of professional, pedagogical, personality, and social competence; Schools that have good and decent infrastructure or can be given proper ones; and students have good and high learning motivation. Matters that need attention from all stakeholders of Education, and further research on this must be added to education in Indonesia in general.
\end{abstract}

Keywords: Curriculum 2013, Infrastructure, Student Learning Motivation, and Teacher Readiness

\begin{abstract}
ABSTRAK
Penelitian melihat bagaimana efektivitas Kesiapan Guru, Infrastruktur, dan Motivasi Belajar Siswa terhadap penerapan Kurikulum 2013 (kurtilas) dan keberlangsungan penerapan Kurikulum 2013 di SMP Kristen Kanaan Tangerang sebagai studi kasus. Metode penelitian yang dipakai adalah penelitian kuantitatif. Populasi meliputi siswa kelas 8 dan 9 SMP Kristen Kanaan Tangerang. Sampel berjumlah 60 orang siswa. Pengumpulan data dilakukan dengan menyebarkan kuesioner secara langsung kepada sampel responden selanjutnya dianalisis menggunakan Program IBM SPSS Statistics 20. Hasil penelitian menunjukkan ada efektivitas dari Kesiapan Guru, Infrastruktur, dan Motivasi Balajar Siswa di SMP Kristen Kanaan Tangerang, baik secara parsial maupun secara bersamasama terhadap Keberhasilan Penerapan Kurikulum 2013. Kesimpulan yang didapat terhadap Keberhasilan Penerapan Kurikulum 2013 setidaknya dapat dicapai dengan adanya kesiapan guru-guru dalam hal kompetensi profesional, pedagogik, kepribadian, dan hubungan sosial; Sekolah seharusnya memiliki infrastruktur yang baik dan memadai atau boleh dikatakan layak; serta siswa sendiri memiliki motivasi belajar yang baik dan tinggi. Hal-hal ini perlu mendapat perhatian dari seluruh stakeholder Pendidikan, dan setidaknya penelitian ini menjadi masukan untuk kemajuan pendidikan di Indonesia pada umumnya.
\end{abstract}

Kata Kunci: Kurikulum 2013, Infrastruktur, Motivasi Belajar Siswa, dan Kesiapan Guru 


\section{PENDAHULUAN}

Berkembangnya ilmu pengetahuan dan teknologi serta dunia ada di era globalisasi, arus informasi begitu cepat menuntut perubahan di berbagai bidang. Tidak terkecuali dalam dunia Pendidikan. Pemerintah, dalam hal ini diwakili Kementerian Pendidikan berkepentingan untuk menyesuaikan sistem Pendidikan untuk menghadapi perubahan yang terjadi, di mana pendidikan kontekstual diterapkan melalui pendekatan pengajaran yang demokratis (democratic teaching) merupakan pilihan alternatif yang ingin diambil secara nasional dan pembaharuan sistem pendidikan nasional berorientasi pada desentralisasi Pendidikan. Hal ini sejalan dengan adanya otonomi daerah, dengan dikeluarkannya Undang-Undang Nomor 20 Tahun 2003 tentang Sistem Pendidikan Nasional dan pelaksanaannya diatur oleh Peraturan Pemerintah Nomor 19 Tahun 2005 tentang Standar Nasional Pendidikan. Wujud nyata penyempurnaan sistem pendidikan nasional dilaksanakan melalui democratic teaching dengan diberlakukan Kurikulum 2004, yaitu Kurikulum Berbasis Kompetensi (KBK) yang berorientasi pada kompetensi atau kemampuan siswa, di mana setiap siswa dapat memahami, mahir, dan menguasai kompetensi yang ditentukan.

Dengan berjalannya waktu kembali pemerintah melakukan perubahan sistem pendidikan, dengan diterapkannya konsep differencial competency teaching dengan diberlakukannya Kurikulum 2006, yaitu Kurikulum Tingkat Satuan Pendidikan (KTSP) yang secara operasional sebagai pelaksanaan desentralisasi pendidikan di sekolah-sekolah yaitu adanya otonomi di bidang pendidikan. Yang menjadi landasan hukum dari pengembangan Kurikulum Tingkat Satuan Pendidikan (KTSP) adalah Permendiknas Nomor 22, 23 dan 24 Tahun 2006.

Mencermati perubahan tantangan dalam dunia pendidikan dan adanya permasalahan pendidikan yang muncul terutama situasi atau kondisi pada tataran operasional pelaksanaan sistem pendidikan Indonesia, pemerintah saat itu memandang perlu untuk memperbaharui Standar Nasional Pendidikan (SNP) dengan diterbitkannya Peraturan Pemerintah (PP) Nomor 32 Tahun 2013 tentang Standar Nasional Pendidikan, merupakan pengganti Permendikbud Nomor 19 tahun 2005, yang kemudian mengembangkan kurikulum baru, yaitu Kurikulum Tahun 2013 (kurtilas), melalui Permendiknas Nomor 64 s.d. Nomor 70 Tahun 2013.

Kementerian Pendidikan Nasional dalam mengembangkan Kurikulum 2013 ini dengan melihat tantangan internal maupun eksternal. Tantangan internal pertama yang dihadapi kondisi pendidikan dihubungkan dengan tuntutan pendidikan yang berdasar pada 8 (delapan) Standar Nasional Pendidikan yang meliputi: 1) Standar Pengelolaan; 2) Standar Biaya; 3) Standar Sarana Prasarana; 4) Standar Pendidik dan Tenaga Kependidikan; 5) 
Standar Isi; 6) Standar Proses; 7) Standar Penilaian; dan 8) Standar Kompetensi Lulusan. Tantangan internal kedua adalah faktor meningkatnya pertumbuhan usia sekolah dan usia produktif penduduk Indonesia. Di sini, perlu antisipasi agar sumberdaya manusia Indonesia memiliki bekal ilmu dan kemampuan yang cukup dan mampu bersaing.

Tantangan eksternal yang dihadapi dunia pendidikan antara lain berkaitan dengan tantangan masa depan, kompetensi yang diperlukan di masa depan, perkembangan ilmu pengetahuan, serta berbagai fenomena negatif yang terjadi. Tantangan di masa depan, di antaranya terkait globalisasi dan masalah lingkungan hidup, perkembangan teknologi dan informasi, kebangkitan industri kreatif, dan perkembangan pendidikan di dunia.

Menteri Pendidikan Nasional pada waktu itu, Mohammad Nuh (Jawa Pos, 27 Januari 2013) menyatakan, bahwa Kurikulum 2013 ini bukan hanya penting, tapi juga genting dan sangat mendesak untuk dilakukan demi masa depan anak-anak Indonesia. Kurikulum 2013 berusaha menjawab kebutuhan kompetensi generasi Indonesia pada tahun 2045 atau 100 tahun sejak Indonesia merdeka. Orientasi pengembangan Kurikulum 2013 adalah tercapainya kompetensi atau kemampuan yang seimbang antara: pengetahuan (kognitif), sikap (afektif), dan keterampilan (psikomotor) menggunakan pembelajaran yang holistik dan menyenangkan.

Dengan adanya Kurikulum 2013, diharapkan guru dapat mengembangkan kreativitasnya dalam mengajar dengan mengarahkan siswa untuk mengamati, bertanya, mengumpulkan informasi, menalar, menyajikan, dan mengkomunikasikan pelajaran yang diberikan guru.

Kemendiknas memandang perlunya perubahan kurikulum menjadi Kurikulum 2013: pertama, untuk mempersiapkan generasi sekarang agar mampu menjawab tantangan masa depan Indonesia. Tuntutan masa depan berubah-ubah, maka kita perlu menyesuaikan kurikulum pendidikan kita; Kedua, substansi perubahan Kurikulum 2013 adalah perubahan pada: Standar Kompetensi Lulusan, Standar Isi (Kompetensi Inti dan Kompetensi Dasar), Standar Proses, dan Standar Penilaian; Ketiga, Kualitas pendidikan Indonesia sudah sangat jauh tertinggal dibandingkan dengan negara lain. Keempat, dengan kurikulum baru diharapkan menghasilkan lulusan dengan kompetensi tinggi dan berpikir analitis (Mendiknas Mohammad Nuh, KOMPAS, 3 Desember 2013).

Namun, perubahan ini tetap saja menimbulkan permasalahan di lapangan. Untuk itu, peneliti mencoba untuk melakukan kajian di beberapa bagian yang menjadi sorotan di masyarakat luas, di antaranya: pertama, apakah guru-guru telah siap dengan perubahan kurikulum dan mengajar berdasar pada Kurikulum 2013. Untuk penerapan kurikulum yang baru perlu dilakukan pelatihan-pelatihan terhadap guru-guru; kedua, infrastruktur atau sarana prasarana belum sepenuhnya siap dan memadai, seperti ruang kelas yang memadai, 
buku paket (buku siswa dan buku pegangan guru) belum dimiliki sekolah-sekolah, kekurangan perangkat komputer yang terhubung ke internet sebagai salah satu sumber belajar penting, juga ruang laboratorium Komputer, laboratorium IPA yang belum memadai di sekolah-sekolah; ketiga, motivasi siswa dalam belajar yang masih rendah, dan juga tidak gampang melakukan perubahan cara belajar dari pembelajaran yang berpusat pada guru (teacher centered learning) kepada pembelajaran yang berpusat pada siswa (student centered learning), juga belum termasuk bertambahnya jam belajar siswa di sekolah yang dapat menyebabkan keletihan, dan semakin banyaknya tugas yang di bawa ke rumah, dan lain-lain.

\section{Kesiapan Guru}

Kata kesiapan berasal dari kata siap yang menurut Kamus Besar Bahasa Indonesia berarti sudah bersedia (untuk). Wasty Soemanto (2006) menyatakan bahwa kesiapan (readiness) merupakan kesediaan seseorang untuk berbuat sesuatu, yang kemudian dapat dituangkan dalam prinsip-prinsip kesiapan, yang meliputi: 1) Aspek perkembangan interaksi seseorang; 2) Pengalaman seseorang mempengaruhi pertumbuhan fisiologis individunya; 3) Pengalaman seseorang mempunyai efek komulatif dalam perkembangan fungsi kepribadian individu, baik jasmani maupun rohani; 4) Kesiapan dasar untuk kegiatan tertentu terbentuk pada diri seseorang merupakan masa perkembangan pribadinya.

Menurut Slameto (2010), kesiapan adalah keseluruhan kondisi seseorang yang membuatnya siap untuk memberi respon atau jawaban dengan cara tertentu terhadap suatu situasi atau kondisi. Kondisi seseorang terdiri dari 3 dimensi, yaitu: 1) kondisi fisik, mental, dan emosional; 2) kebutuhan, motivasi, dan tujuan; dan 3) keterampilan, pengetahuan dan hal lain yang telah dipelajarinya.

\section{Infrastruktur}

Kualitas pendidikan yang baik didukung infrastruktur yang baik pula, di mana hal ini dapat menunjang kualitas belajar siswa. Sekolah yang memiliki fasilitas laboratorium komputer misalnya, setidaknya siswa secara langsung dapat belajar komputer dan menggunakannya untuk kebutuhan pembelajarannya. Infrastruktur yang dibutuhkan sekolah perlu direncanakan dan dikelola dengan cermat sehingga mendukung semua proses pembelajaran yang efektif dan efisien.

Mustari (2014:119) mengatakan ketersediaan infrastruktur, yang terdiri dari sarana dan prasarana merupakan salah satu komponen penting yang harus terpenuhi dalam menunjang manajemen pendidikan yang baik. Lebih lanjut disampaikan bahwa sarana dan prasarana 
pendidikan itu sebaiknya dikelola dengan sebaik mungkin dengan mengikuti kebutuhankebutuhan sebagai berikut:

1. Lengkap, siap dipakai setiap saat, kuat dan awet.

2. Rapi, indah, bersih, anggun, dan asri sehingga menyejukkan pandangan dan perasaan siapapun yang memasuki kompleks sekolah.

3. Kreatif, inovatif, responsif dan bervariasi sehingga dapat merangsang timbulnya imajinasi peserta didik.

4. Memiliki jangkauan waktu yang panjang melalui perencanaan yang matang untuk menghindari kecenderungan bongkar pasang bangunan.

5. Memiliki tempat khusus untuk beribadah maupun pelaksanaan kegiatan sosio-religius seperti musala atau masjid (Qomar, 2005).

Berdasarkan Peraturan Menteri Pendidikan Nasional Nomor 24 Tahun 2007 Tanggal 28 Juni 2007 tentang Standar Sarana dan Prasarana Sekolah/Madrasah Pendidikan Umum, menyatakan bahwa SMP/MTs sekurang-kurangnya memiliki: (1) Ruang kelas, (2) Ruang perpustakaan, (3) Ruang laboratorium IPA, (4) Ruang pimpinan/Kepala Sekolah, (5) Ruang guru, (6) Ruang Tata Usaha (TU), (7) Tempat beribadah, (8) Ruang Bimbingan Konseling (BK), (9) Ruang UKS (unit kesehatan sekolah), (10) Ruang organisasi kesiswaan (OSIS), (11) Jamban/WC, (12) Gudang, (13) Ruang sirkulasi, (14) Tempat bermain/lapangan olahraga.

\section{Motivasi Belajar Siswa}

Winkel (2009) menyampaikan bahwa motivasi belajar siswa merupakan faktor psikis yang bersifat non-intelektual, dan peranannya yang khas adalah gairah atau semangat belajar, sehingga seorang siswa yang bermotivasi kuat akan memiliki energi yang besar untuk melakukan kegiatan belajar. Siswa yang mempunyai motivasi kuat, akan mempunyai semangat dan gairah belajar yang tinggi, dan akan mencapai prestasi belajar yang tinggi pula.

Ada tiga hal yang berkaitan dengan motivasi, yaitu: 1) kebutuhan; 2) dorongan; dan 3) tujuan. Siswa yang termotivasi akan menunjukkan reaksi yang mengarahkan dirinya untuk mencapai tujuan, seperti untuk dapat dihargai, dan diakui oleh orang lain.

Salah satu cara untuk mengukur dan menjelaskan motivasi belajar siswa adalah dengan menggunakan instrumen model pembelajaran ARCS, yaitu: perhatian (attention), hubungan (relevance), kepercayaan diri (confidence), kepuasan (satisfaction). Model pembelajaran ARCS merupakan bentuk pendekatan pemecahan masalah untuk merancang aspek 
motivasi serta lingkungan belajar dalam mendorong dan mempertahankan motivasi siswa untuk belajar (Keller, 1987). Model ini berkaitan erat dengan motivasi siswa terutama motivasi untuk memperoleh pengetahuan yang baru.

Dalam melakukan penilaian motivasi belajar siswa dibutuhkan aspek-aspek yang terukur. Keke T. Aritonang (2008) mencatat aspek-aspek penilaian motivasi belajar siswa yang meliputi beberapa dimensi yang dapat dijadikan indikator, yaitu:

1. Ketekunan dalam belajar
a. Kehadiran di sekolah
b. Mengikuti KBM di kelas
C. Belajar di rumah

2. Ulet dalam menghadapi kesulitan
a. Sikap terhadap kesulitan
b. Usaha mengatasi kesulitan

3. Minat dan ketajaman perhatian dalam belajar
a. Kebiasaan dalam mengikuti pelajaran
b. Semangat dalam mengikuti KBM

4. Berprestasi dalam belajar

a. Keinginan untuk berprestasi

b. Kualifikasi hasil

5. Mandiri dalam belajar
a. Penyelesaian tugas/PR
b. Menggunakan kesempatan di luar jam pelajaran

\section{Kurikulum 2013}

Menurut Kamus Besar Bahasa Indonesia, kurikulum adalah perangkat mata pelajaran yang diajarkan pada lembaga Pendidikan. Ornstein, Allan \& Hunkins (2013:9) menyatakan bahwa "curriculum can be defined as a field of study with its own foundations, knowledge domain, research, theory, principles, and specialist". (Kurikulum dapat didefinisikan sebagai bidang studi dengan pondasi sendiri, ranah pengetahuan, penelitian, teori, prinsip, dan spesialisasi).

Pandangan lain mengenai definisi kurikulum dikemukan oleh Hamalik, 2008 (dalam Mustari, 2014:53), kurikulum adalah seperangkat rencana dan pengaturan mengenai tujuan, isi, dan bahan pelajaran serta cara yang digunakan sebagai pedoman penyelenggaraan kegiatan pembelajaran untuk mencapai tujuan pendidikan tertentu. 
Sedangkan pengertian kurikulum menurut Undang-Undang No. 20 tahun 2003, Pasal 1 ayat 19 adalah seperangkat rencana dan pengaturan mengenai tujuan, isi dan bahan pelajaran serta cara yang digunakan sebagai pedoman penyelenggaraan kegiatan pembelajaran untuk mencapai tujuan pendidikan tertentu.

Kurikulum merupakan inti dari proses pendidikan, karena kurikulum pengajaran merupakan bidang yang paling langsung berpengaruh terhadap hasil pendidikan. Dalam pengembangan kurikulum, minimal dapat dibedakan antara desain kurikulum atau kurikulum tertulis (curriculum plan) dan implementasi kurikulum atau kurikulum fungsional (functioning curriculum).

Kurikulum 2013 adalah rancang bangun dari pembelajaran yang didesain untuk mengembangkan potensi peserta didik, yang bertujuan untuk mewujudkan generasi bangsa Indonesia yang bermartabat, beradab, berbudaya, berkarakter, beriman dan bertakwa kepada Tuhan Yang Maha Esa, berakhlak mulia, sehat, berilmu, cakap, kreatif, mandiri, menjadi warga negara yang demokratis, dan bertanggung jawab yang mulai dioperasikan pada tahun pelajaran 2013/2014 secara bertahap (Kemendikbud, 2013).

Sebagai landasan filosofis program pengembangan Kurikulum 2013 adalah potensi, peluang yang dimiliki serta kemungkinan kendala yang ada. Pertama, Pendidikan berakar pada budaya bangsa untuk membangun kehidupan bangsa masa kini dan masa mendatang. Pandangan ini menjadikan Kurikulum 2013 dikembangkan berdasarkan budaya bangsa Indonesia yang beragam, diarahkan untuk membangun kehidupan masa kini, dan untuk membangun dasar bagi kehidupan bangsa yang lebih baik di masa depan. Kedua, Peserta didik adalah pewaris budaya bangsa yang kreatif. Menurut pandangan filosofi ini, prestasi bangsa di berbagai bidang kehidupan di masa lampau adalah sesuatu yang harus termuat dalam isi kurikulum untuk dipelajari peserta didik. Ketiga, Pendidikan ditujukan untuk mengembangkan kecerdasan intelektual dan kecemerlangan akademik melalui pendidikan disiplin ilmu. Filosofi ini menentukan bahwa isi kurikulum adalah disiplin ilmu dan pembelajaran adalah pembelajaran disiplin ilmu (essentialism). Keempat, Pendidikan untuk membangun kehidupan masa kini dan masa depan yang lebih baik dari masa lalu dengan berbagai kemampuan intelektual, kemampuan berkomunikasi, sikap sosial, kepedulian, dan berpartisipasi untuk membangun kehidupan masyarakat dan bangsa yang lebih baik (experimentalism and social reconstructivism).

Langkah-langkah penguatan tata kelola Kurikulum 2013 terdiri atas: 1) menyiapkan buku pegangan pembelajaran bagi siswa dan guru; 2) menyiapkan guru supaya memahami pemanfaatan sumber belajar yang telah disiapkan dan sumber lain yang dapat mereka 
manfaatkan; serta 3) memperkuat peran pendampingan dan pemantauan oleh pusat dan daerah pelaksanaan pembelajaran.

Kurikulum 2013 juga akan menerapkan sistem evaluasi baru untuk melihat keberhasilan pencapaian proses belajar mengajar. Jika selama ini tes sangat dominan dalam evaluasi maka dalam kurikulum baru tes akan dikombinasikan dengan penilaian portofolio. Pertimbangannya, tes hanya mampu menilai kognitif siswa semata sementara afektif dan psikomotorik siswa tidak akan tersentuh. Oleh karena itu sistem evaluasi baru ini diharapkan akan mampu mengukur pencapaian siswa secara konprehensif. Bagaimanapun ini juga membutuhkan kesiapan dari guru.

Sedikitnya ada dua faktor besar dalam keberhasilan penerapan Kurikulum 2013. Pertama, faktor penentu yang berkenaan dengan kesesuaian kompetensi pendidik dan tenaga kependidikan dengan kurikulum dan buku teks. Kedua, faktor pendukung yang terdiri dari tiga unsur, yaitu: 1) ketersediaan buku sebagai sumber belajar yang mengintegrasikan standar pembentuk kurikulum; 2) penguatan peran pemerintah dalam pembinaan dan pengawasan; dan 3) penguatan manajemen dan budaya sekolah.

\section{METODOLOGI PENELITIAN}

Populasi pada penelitian ini meliputi kelas 8 dan 9 SMP Kristen Kanaan Tangerang Tahun Pelajaran 2015-2016 yang berjumlah 134 orang. Teknik pengambilan sampel dilakukan menggunakan simple random sampling, diperoleh 60 orang responden. Instrumen yang digunakan adalah kuisioner yang terdiri atas pernyataan-pernyataan berkisar tentang variabel Kesiapan Guru, Infrastruktur, Motivasi Belajar Siswa dan Keberhasilan Penerapan Kurikulum 2013.

\section{HASIL DAN PEMBAHASAN}

\section{Uji t}

1. Uji t untuk mengetahui efektivitas Variabel $X 1$ terhadap $Y$

Dari hasil perhitungan SPSS untuk mengetahui efektivitas variabel Kesiapan Guru (X1) terhadap Keberhasilan Penerapan Kurikulum 2013 (Y) didapat hasil seperti terlihat pada tabel t hitung efektivitas Variabel $\mathrm{X} 1$ terhadap $\mathrm{Y}$ : 


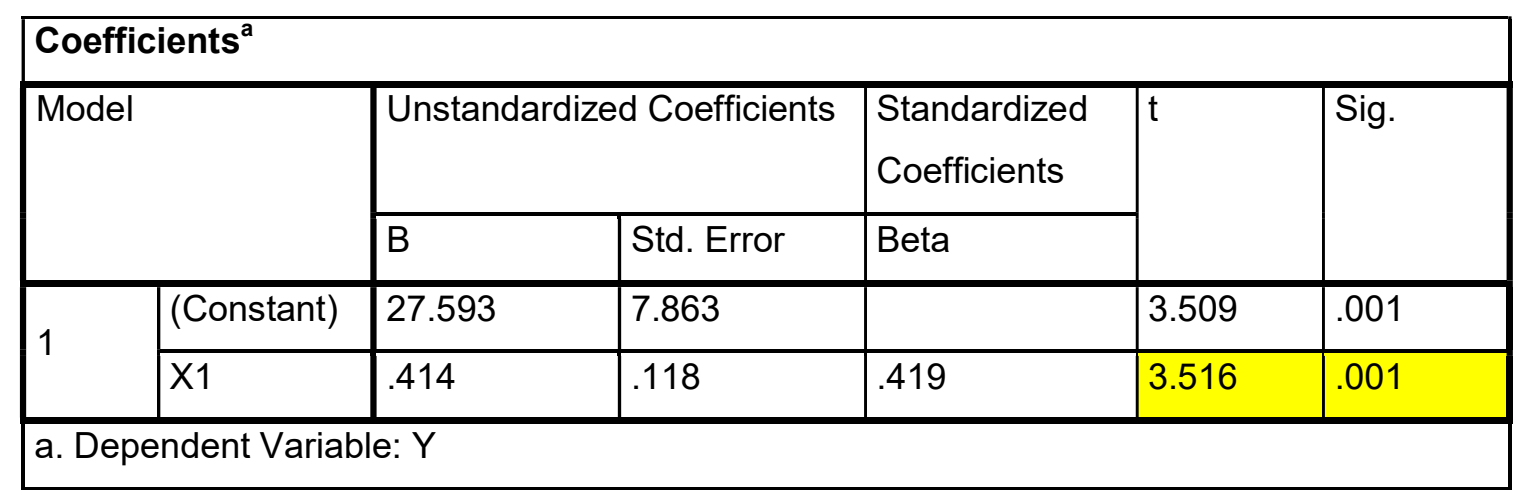

Dari tabel di atas diperoleh nilai t hitung sebesar 3,516 dan nilai signifikansi $0,001<$ 0,05 , sedangkan $t$ tabel $=2,002$. Ini berarti $t$ hitung $(3,516)>t$ tabel $(2,002)$ sehingga $H_{0}$ ditolak dan $\mathrm{H}_{\mathrm{a}}$ diterima. Kesimpulannya bahwa ada efektivitas antara variabel Kesiapan Guru (X1) dengan Keberhasilan Penerapan Kurikulum 2013 (Y). Gambar berikut ini untuk melihat kedudukan thitung variabel $\mathrm{X} 1$ :

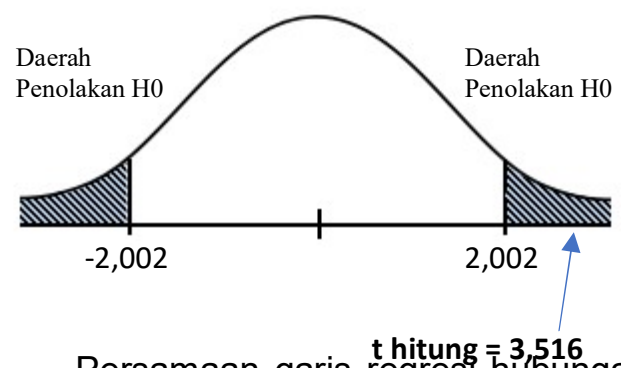

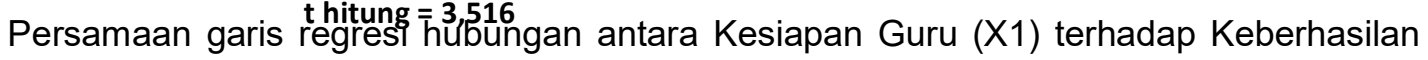
Penerapan Kurikulum 2013 (Y) dapat dinyatakan dengan:

$Y=27,593+0,414 \times 1$

Persamaan tersebut menunjukkan bahwa ni apabila Kesiapan Guru (X1) meningkat 1 poin 2013 (Y) akan meningkat 0,414 poin.

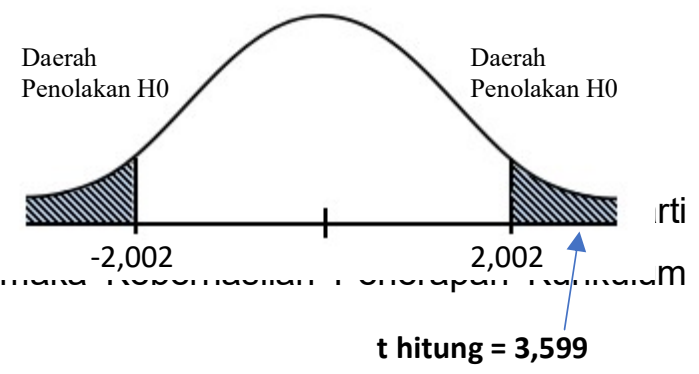

2. Uji t untuk mengetahui efektivitas Variabel $X 2$ terhadap $Y$

Dari hasil perhitungan SPSS untuk mengetahui efektivitas variabel Infrastruktur (X2) terhadap Keberhasilan Penerapan Kurikulum 2013 (Y) didapat hasil seperti terlihat pada tabel t hitung efektivitas Variabel $\mathrm{X} 2$ terhadap $\mathrm{Y}$ : 


\begin{tabular}{|l|l|l|l|l|l|l|}
\hline \multicolumn{2}{|l|}{ Coefficients $^{\mathbf{a}}$} & \multicolumn{2}{l|}{ Unstandardized Coefficients } & $\begin{array}{l}\text { Standardized } \\
\text { Coefficients }\end{array}$ & $\mathrm{t}$ & Sig. \\
\cline { 2 - 7 } & $\mathrm{B}$ & Std. Error & Beta & & \\
\hline \multirow{2}{*}{1} & (Constant) & 36.767 & 5.180 & & 7.098 & .000 \\
\cline { 2 - 7 } & $\mathrm{X} 2$ & .327 & .091 & .427 & 3.599 & .001 \\
\hline \multicolumn{2}{|l|}{ a. Dependent Variable: Y }
\end{tabular}

Dari tabel di atas diperoleh nilai t hitung sebesar 3,599 dan nilai signifikansi 0,001< 0,05 , sedangkan $t$ tabel $=2,002$. Ini berarti t hitung $(3,599)>t$ tabel $(2,002)$ sehingga $H_{0}$ ditolak dan $\mathrm{H}_{\mathrm{a}}$ diterima. Kesimpulannya bahwa ada efektivitas antara variabel Infrastruktur (X2) dengan Keberhasilan Penerapan Kurikulum 2013 (Y). Gambar berikut ini untuk melihat kedudukan thitung variabel $\mathrm{X} 2$ :

Persamaan garis regresi hubungan antara Infrastruktur (X2) terhadap Keberhasilan Penerapan Kurikulum 2013 (Y) dapat dinyatakan dengan:

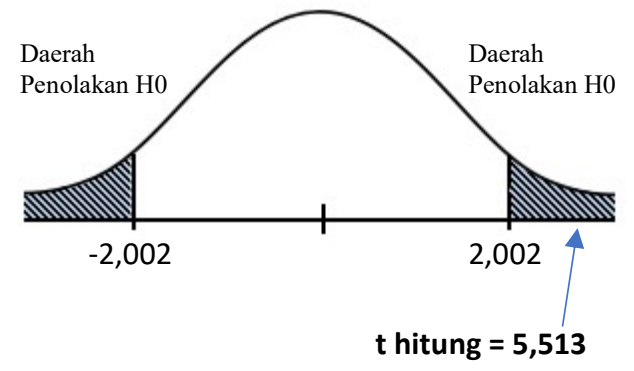

$Y=36,767+0,327 \times 2$

Persamaan tersebut menunjukkan bahwa nilai koefisien X2 sebesar 0,414 yang berarti apabila Infrastruktur (X2) meningkat 1 poin maka Keberhasilan Penerapan Kurikulum 2013 (Y) akan meningkat 0,327 poin.

3. Uji t untuk Mengetahui efektivitas Variabel X3 terhadap $Y$

Dari hasil perhitungan SPSS untuk mengetahui efektivitas variabel Motivasi Belajar Siswa (X3) terhadap Keberhasilan Penerapan Kurikulum 2013 (Y) didapat hasil seperti terlihat pada tabel t hitung efektivitas Variabel $\mathrm{X} 3$ terhadap $\mathrm{Y}$ :

\begin{tabular}{|l|l|l|l|l|l|}
\hline Coefficients $^{\mathbf{a}}$ & \multicolumn{3}{|l|}{ Unstandardized Coefficients } & $\begin{array}{l}\text { Standardized } \\
\text { Coefficients }\end{array}$ & $\mathrm{t}$ \\
\cline { 2 - 4 } & Bodel & Std. Error & Beta & Sig. \\
\hline
\end{tabular}




\begin{tabular}{|l|l|l|l|l|l|l|}
\hline \multirow{2}{*}{1} & (Constant) & 13.697 & 7.552 & & 1.814 & .075 \\
\cline { 2 - 7 } & $\mathrm{X} 3$ & .629 & .114 & .586 & 5.513 & .000 \\
\hline \multicolumn{2}{|l}{ a. Dependent Variable: $\mathrm{Y}$} \\
\hline
\end{tabular}

Dari tabel di atas diperoleh nilai $\mathrm{t}$ hitung sebesar 3,599 dan nilai signifikansi $0,000<$ 0,05 , sedangkan $t$ tabel $=2,002$. Ini berarti t hitung $(5,513)>t$ tabel $(2,002)$ sehingga $H_{0}$ ditolak dan $\mathrm{H}_{a}$ diterima. Kesimpulannya bahwa ada efektivitas antara variabel Motivasi Belajar Siswa (X3) dengan Keberhasilan Penerapan Kurikulum 2013 (Y). Gambar berikut ini untuk melihat kedudukan t hitung variabel $\mathrm{X} 3$ :

Persamaan garis regresi hubungan antara Motivasi Belajar Siswa (X3) terhadap Keberhasilan Penerapan Kurikulum 2013 (Y) dapat dinyatakan dengan:

$Y=13,697+0,629 \times 3$

Persamaan tersebut menunjukkan bahwa nilai koefisien X3 sebesar 0,629 yang berarti apabila Motivasi Belajar Siswa (X3) meningkat 1 poin maka Keberhasilan Penerapan Kurikulum 2013 (Y) akan meningkat 0,629 poin.

\section{Uji F}

Dari hasil perhitungan SPSS untuk efektivitas variabel Kesiapan Guru (X1), Infrastruktur (X2), dan Motivasi Belajar Siswa (X3) secara bersama-sama terhadap Keberhasilan Penerapan Kurikulum 2013 (Y) didapat hasil seperti terlihat pada tabel Anova test Variabel $\mathrm{X} 1, \mathrm{X} 2$, dan $\mathrm{X} 3$ secara bersama-sama terhadap $\mathrm{Y}$ :

\begin{tabular}{|l|l|l|l|l|l|l|}
\hline ANOVA $^{\text {a }}$ & $\begin{array}{l}\text { Sum } \\
\text { Sodel }\end{array}$ & of & df & Mean Square & F & Sig. \\
\hline \multirow{3}{*}{1} & Regression & 2298.871 & 3 & 766.290 & 12.450 & $.000^{\mathrm{b}}$ \\
\cline { 2 - 8 } & Residual & 3446.863 & 56 & 61.551 & & \\
\cline { 2 - 8 } & Total & 5745.733 & 59 & & & \\
\hline \multicolumn{2}{|l|}{ a. Dependent Variable: Y } \\
\hline \multicolumn{2}{|l|}{ b. Predictors: (Constant), X3, X2, X1 } \\
\hline
\end{tabular}


Dari tabel di atas diperoleh nilai $F$ hitung sebesar 12,450 dan nilai signifikansi $0,00<$ 0,05 , sedangkan $F$ tabel $(v 1=3, v 2=59,5 \%)=2,76$. Ini berarti $F$ hitung $(12,450)>F$ tabel $(2,76)$ dan signifikansi $0,000<0,05$ sehingga $\mathrm{H}_{0}$ ditolak dan $\mathrm{H}_{\mathrm{a}}$ diterima.

Kesimpulannya bahwa ada efektivitas variabel Kesiapan Guru (X1), Infrastruktur (X2), dan Motivasi Belajar Siswa (X3) secara bersama-sama terhadap Keberhasilan Penerapan Kurikulum 2013 (Y).

Berikut ini table Persamaan Regresi Variabel X1, X2, dan X3 secara bersama-sama terhadap Y:

\begin{tabular}{|c|c|c|c|c|c|c|}
\hline \multicolumn{7}{|c|}{ Coefficients $^{a}$} \\
\hline \multirow{3}{*}{\multicolumn{2}{|c|}{ Model }} & \multirow{2}{*}{\multicolumn{2}{|c|}{$\begin{array}{l}\text { Unstandardized } \\
\text { Coefficients }\end{array}$}} & \multirow{3}{*}{$\begin{array}{l}\text { Standardized } \\
\text { Coefficients } \\
\text { Beta }\end{array}$} & \multirow[t]{3}{*}{$t$} & \multirow[t]{3}{*}{ Sig. } \\
\hline & & & & & & \\
\hline & & $B$ & Std. Error & & & \\
\hline \multirow{4}{*}{1} & (Constant) & 8.300 & 8.135 & & 1.020 & .312 \\
\hline & $\mathrm{X} 1$ & .045 & .132 & .046 & .341 & .735 \\
\hline & $\mathrm{X} 2$ & .179 & .094 & .233 & 1.908 & .061 \\
\hline & X3 & .515 & .131 & .480 & 3.923 & .000 \\
\hline
\end{tabular}

Dari tabel di atas diperoleh nilai persamaan regresi efektivitas Kesiapan Guru (X1), Infrastruktur (X2), dan Motivasi Belajar Siswa (X3) secara bersama-sama ter-hadap Keberhasilan Penerapan Kurikulum 2013 (Y) dapat dinyatakan dengan:

$Y=8,300+0,045 X 1+0,179 X 2+0,515 X 3$

Persamaan tersebut menunjukkan bahwa nilai koefisien X1 sebesar 0,045 yang berarti apabila Kesiapan Guru (X1) bertambah 1 poin maka Keberhasilan Penerapan Kurikulum 2013 (Y) akan meningkat 0,045 poin dengan asumsi X2 dan X3 tetap. Koefisien X2 sebesar 0,179 yang berarti apabila Infrastruktur (X2) meningkat 1 poin maka Keberhasilan Penerapan Kurikulum 2013 (Y) akan meningkat 0,179 poin dengan asumsi X1 dan X3 tetap. Koefisien X3 sebesar 0,515 yang berarti apabila Motivasi Belajar Siswa (X3) meningkat 1 poin maka Keberhasilan Penerapan Kurikulum 2013 (Y) akan meningkat 0,515 poin dengan asumsi X1 dan X2 tetap.

\section{Uji Koefisien Determinasi (R Square)}


Dari hasil perhitungan SPSS untuk besar efektivitas antara variabel Kesiapan Guru (X1), Infrastruktur (X2), dan Motivasi Belajar Siswa (X3) secara bersama-sama terhadap Keberhasilan Penerapan Kurikulum 2013 (Y) didapat hasil seperti terlihat pada tabel Koefisien Determinasi X1, X2, dan X3 secara bersama-sama terhadap Y:

\begin{tabular}{|c|c|c|c|c|}
\hline \multicolumn{5}{|c|}{ Model Summary } \\
\hline Model & $R$ & R Square & Adjusted R Square & $\begin{array}{l}\text { Std. Error of the } \\
\text { Estimate }\end{array}$ \\
\hline 1 & $.633^{\mathrm{a}}$ & .400 & .368 & 7.845 \\
\hline
\end{tabular}

Dari tabel di atas diperoleh nilai $R$ sebesar 0,633 berarti Kesiapan Guru (X1), Infrastruktur (X2), dan Motivasi Belajar Siswa (X3) secara bersama-sama memiliki efektivitas positif terhadap Keberhasilan Penerapan Kurikulum 2013 (Y).

Kemudian Koefisien R square sebesar 0,400 yang berarti bahwa Kesiapan Guru (X1), Infrastruktur (X2), dan Motivasi Belajar Siswa (X3) secara bersama-sama mampu menerangkan variasi sebesar $40 \%$ perubahan pada Keberhasilan Penerapan Kurikulum $2013(Y)$, sedangkan 60\% dipengaruhi faktor lain di luar penelitian ini.

\section{KESIMPULAN DAN SARAN}

\section{Kesimpulan}

Pertama, terdapat efektivitas positif dan signifikan pada Kesiapan Guru terhadap Keberhasilan Penerapan Kurikulum 2013 di SMP Kristen Kanaan Tangerang; kedua, terdapat efektivitas positif dan signifikan pada Infrastruktur terhadap Keberhasilan Penerapan Kurikulum 2013; Ketiga, terdapat efektivitas positif dan signifikan pada Motivasi Belajar Siswa terhadap Keberhasilan Penerapan Kurikulum 2013; keempat, terdapat efektivitas positif dan signifikan pada Kesiapan Guru, Infrastruktur dan Motivasi Belajar Siswa secara bersama-sama terhadap Keberhasilan Penerapan Kurikulum 2013 di SMP Kristen Kanaan Tangerang.

\section{Saran}

1. Untuk Guru

Para guru perlu lebih meningkatkan kepribadian dalam hal ini kewibawaan dan keteladanan karena hal ini mendapat persepsi terendah dari para siswa. Guru harus bersikap tegas dan bijaksana terhadap siswa untuk menciptakan suasana belajar yang aktif, kreatif, efektif dan menyenangkan. 


\section{Untuk Infrastruktur Sekolah}

Perlu perbaikan dan melengkapi Infrastruktur di SMP Kristen Kanaan Tangerang, misalnya menyediakan sarana alat peraga dan media pembelajaran lebih banyak, buku pelajaran dan buku pendukung berkenaan dengan Kurikulum 2013 di perpustakaan yang masih kurang banyak dan bervariasi, dan juga prasarana, seperti ruang praktek yang perlu diperluas dan alat-alat praktikum perlu dilengkapi dan ditambah untuk mendukung pembelajaran siswa.

3. Untuk Siswa

Agar setiap siswa meningkatkan motivasi belajarnya dalam hal ini minat dan ketajaman perhatian dalam belajar serta kemandirian dalam belajar karena hal ini mendapat persepsi terendah menurut para siswa sendiri. Siswa harus bersemangat mengikuti pelajaran dan memperhatikan jika guru menerangkan serta dapat memanfaatkan waktu yang ada dengan belajar sungguh-sungguh secara mandiri. Yang tidak kalah pentingnya siswa tidak membeda-bedakan guru yang satu dengan yang lain atau memilih guru-guru yang disukai saja.

\section{ACUAN PUSTAKA}

Hamalik, O. (2013). Dasar-Dasar Pengembangan Kurikulum. Bandung: PT. Remaja Rosdakarya.

Aritonang, K. T. (2008). Minat dan Motivasi Dalam Meningkatkan Hasil Belajar Siswa. Jurnal Pendidikan Penabur: Badan Pendidikan Kristen Penabur. Vol. 7 No. 10, Juni 2008.

Mustari, M. (2014). Manajemen Pendidikan. Jakarta: PT. RajaGrafindo Persada.

Ornstein, A. C. and Hunkins, F. P. (2013). Curriculum: Foundations, Principles, and Issues (Sixth Edition). Boston: Pearson.

Sardiman, A. M. (2014). Interaksi dan Motivasi Belajar Mengajar (cetakan ke-22). Jakarta: PT. RajaGrafindo Persada.

Schunk, D. H. (2012). Learning Theories:an Educational Perspective (Sixth Edition). Boston: Pearson.

Sugiyono (2012). Statistika Untuk Penelitian (edisi ketiga, cetakan ke-21). Bandung: CV. Alfabeta.

Slameto (2010). Belajar dan Faktor-Faktor yang Mempengaruhinya. Jakarta: Rineka Cipta.

Sumanto, W. (2006). Psikologi Pendidikan (Landasan Kerja Pemimpin Pendidikan). Jakarta: Rineka Cipta.

Sutermeister, R. A. (2003). People and Productivity (Five Edition). New York: McGrow Hill Book Company. 
Puspitasari, W. (2013). Analisis Prinsip Pengembangan Kurikulum 2013 berdasarkan Bahan

Uji Publik Kurikulum 2013. Fakultas Pendidikan Matematika Dan Ilmu Pengetahuan Alam: Universitas Pendidikan Indonesia. 2 April 2013.

Winkel, W.S. (2009). Psikologi Pengajaran. Jakarta: Media Abadi.

Hidayat, Y. (2013). Kekurangan dan Kelebihan Kurikulum 2013. 4 Desember 2013. 
JDP Volume 12, Nomor 1, April 2019: 1-15 